\title{
REVISITING GENDER TOUGHT IN ISLAMIC STUDIES
}

\author{
Karimatul Khasanah \\ IAIN Purwokerto \\ karima@iainpurwokerto.ac.id
}

\begin{abstract}
Women issue viewed from religions perspective will be always interesting to study. It is because religion often does "not bridging" the role of women as creatures who share a humanitarian and divine mission, like men, instead it makes the position of women subordinated and marginalized. Related to the discourse on gender, this paper responds to find the root of the problem out by making modern thinkers as a foothold, namely Amina Wadud and Khaled Abou El-Fadl. Amina Wadud introduces tauhidi hermeneutics which can be used as a paradigm and methodology. Meanwhile El-Fadl introduces a dialogical hermeneutics to bridge the imbalance of subjectivity elements that often occur in gender interpretation.
\end{abstract}

Keywords: gender, Amina Wadud, Khaled Abou El-Fadl, Hermeneutics

\section{A. Introduction}

T Tomen are always hospitable with religion, but religion is not always hospitable with them. ${ }^{1}$ It is a fine phrase quoted from MorizWinternitz as a critique to religion and its relevance to the position and dignity of women. In Islam, hinted at by some verses of the Qur'an, the Eve tends to get a more discriminating position than the Adam. We can see some cases, like the verses about human creation, leadership, Divorce rights, inheritance rights, and so forth, women always get a position under men. This becomes absurd when we re-read the Islamic jargon echoed in the Qur'an that it is a mercy to the whole of universe.

All these problems are important in their relevance to religion. In this case, Islamic thought has a considerable responsibility to create male and female relations in the contemporary era, where human right places an important element in the life of every individual. Since the modern era, where the tide of freedom has begun to emerge, the freedom of human beings who pivot on human rights, to be respected and honored and the principle of equality between men and women began to emerge and influence in the realm of

\footnotetext{
${ }^{1}$ Hamim Ilyas, Islam dan Pembongkaran Nalar Bias Patriarkhi, Pengantar II, dalam Aksin Wijaya, Menggugat Otentisitas Wahyu Tuhan; Kritik Atas Nalar Tafsir Gender (Yogyakarta: Safiria Insania Press, 2004), xvii.
} 
religious thought. ${ }^{2}$ At this point, many scholars who try to re-read with a modern religious spirit, some of them will be explored by the writer here. They are Amina Wadud and Khaled Abou El-Fadl. Both are contemporary Muslim thinkers who have a feminine dimension in their thinking as well as having special experience in their interactions with religious systems that tend to be monolithic, patriarchal and discriminatory.

\section{B. Gender and the Academic Anxiety}

Some efforts to reconstruct a thoughtful about gender begin to re-look at the formation of women's identity from a religious perspective, because religion occupies a central position in the formation and attachment of identity to believers. This is what makes religion a more attracting source to study. Epistemologically, religious texts becomes an important foundation in term of developing religious thought. Therefore, a reunderstanding religious text becomes a very fundamental element. Taking the term Thomas Kuhn, popularized by Amin Abdullah, ${ }^{3}$ that what we need today is a shifting paradigm in reading clasical intellectual inharitance (hasanah turath). Letting the old texts be, but the way or paradigm of reading the text should evolve and not be fixed on the classical paradigm construction. That way, the text will return fresh because it comes with new meanings presenting in the contemporary spaces. Similarly, gender-related issues, repositioning and identity struggles of women must also be placed within the framework of shifting paradigm of understanding, because if we left them unchecked without any critical effort, it will be boomerang for religion, because religion will be considered an "obsolete" and considered to inhibit the rate current development.

Amina Wadud's fretfulness toward Islamic studies revolves around the formation of female identity. The format inherent in the dynamics of Islamic studies often makes women distorted, so it is natural that women are marginalized by the "power" of knowledge and hegemony. The issue of women marginalization is very massive and occurs in the various spheres of human life either, social, economic, political, or spiritual sphere. The basic assumption built by Amina Wadud is that the Qur'an is the basis of knowledge, so that studying the Qur'an in order to reconstruct gender thinking is a necessity, because through the Qur'an Islamic thought emerges with a various alternatives.

Amina Wadud, hence, underlines two important points on gender issues: first, the limitation of women's role in the ethical-spiritual and social-political spheres. The limitations of women's roles are not uncausing, but rather because of the monolithic roles of religious leaders or religious institutions and the pressure of commentators who twist the meaning of

\footnotetext{
${ }^{2}$ Amin Abdullah, "Pengantar Rektor UIN Sunan Kalijaga" in Susilaningsih and Agus M. Najib, Kesetaraan Gender di Perguruan Islam; Baseline and Institutional Analysis for Gender Mainstreaming in IAIN Sunan Kalijaga (Yogyakarta: UIN Sunan Kalijaga dan McGill, 2004), vx-vxi.

${ }^{3}$ Imam Anas Muslihin, Signifikansi Hermeneutika Dalam Kajian Hukum Islam Kontemporer (Studi Atas Pemikiran Khaled Abou El-Fadl), Yogyakarta, UIN Sunan Kalijaga, a paper presented on 13 Januari 2014.
} 
the Qur'an in a more patriarchal approach. ${ }^{4}$ Second, the lack of literature departing from the perspective of women. Religious texts are often patriarchal because the determinants (interpreuter) of the meaning of the text are male. For many years, the majority of the exegetes were dominated by men, and perhaps only Bint as-Shati' was the first woman interpreuter to be popular with the first female mufassir. The majority of readings are on the part of the man of course affect style of the existing interpretation. And with the perspective of women in re-reading sacred text is expected to give the balance of thought in interpreting the texts that full of gender bias.

Different with Amina Wadud, Khaled Abou El-Fadl actually had been bothered with existence of institutions representing Islam and giving a number of fatwas that he deems less relevant to the context, even discrediting women. A number of institutions which became object of study are SAS (the Society for Adherence to the Sunnah) in America and CRLO (Council for Scientific Research and Legal Opinions al-lajnah al-dāimah li al-buhuth al'ilmiyah wa al-iftā) In Saudi Arabia. The peculiarities that exist in these two religious institutions could be seen from the references of hadiths which are the source of fatwas and the use of logic which is also bias and odd. ${ }^{5}$ That is the background and inspiration of Khaled to pour his mind and then produced many papers. One of his works which is quite popular in criticizing authoritarian groups in the name of God is "And God Knows the Soldiers: A concise yet powerful and accessible work on Sharia in action", "Speaking in God's Name: Islamic Law, Authority and Women". 6

\section{Reading Gender in A Contemporary Perspective \\ a. Tauhïdi Hermeneutics Amina Wadud}

The fundamental idea promoted by Amina Wadud in reconstructing Islamic gender thinking is about equality between men and women. In various verses, God does not actually distinguish the two human entities functionally. They share the same mission of divinity and humanity on earth as khalifatullah. This basic assumption is very influential in the character of Amina Wadud's thought to build his tafsir thinking. With the principle of equality based on the meaning khalifah Allăh, men should not dominate and marginalize women as being backward. Because women are naturally also have an opportunity to play a role in advancing civilization.

Based on this view Amina Wadud later introduced "tauhidi hermeneutics ", a term that may be the main attraction and become his trademark. This tauhidi hermeneutics more or less revolves around two main axes: as a methodology and a paradigm. As a

\footnotetext{
${ }^{4}$ Wijaya, Menggugat, 157.

${ }^{5}$ Yusriandi, Hermeneutika Hadis Khaled Abou El Fadl in Hermeneutika al-Qur'an dan Hadis, (ed) Sahiron Syamsuddin (Yogyakarta: eLSAQ Press, 2010), 415.

${ }^{6}$ http://www.scholarofthehouse.org/biofkhabelfa.html. Accessed on Mei 20, 2017.
}

Teosofia: Indonesian Journal of Islamic Mysticism, Volume 6, Number 1, 2017 
methodology, tauhidi hermeneutics refers to holistic, organized, dialogical and thematic stages. This method is considered as an alternative to get the picture and spirit (worldview) of the Qur'an about the issue of women in it. At first glance, the previously mentioned verses illustrate the existence of an outward contradiction. Hopefully the usage of tauhid $\bar{i}$ hermeneutics is to uncover the connection, coherence, and unity of mission of the Qur'an about women affairs.

The tauhidi Hermeneutics intended by Amina Wadud in the methodological applicative realm revolves around the organic reading spaces, a method of reading by collecting whole verses that speak of a theme and then interpreted in a hierarchical and dialogical manner. This method is an antithesis to the methods of earlier scholars who tend to be atomistic. The scholars have put forward the analytic (tah/ili) aspect of a verse and tend to ignore the dialogue of verses in the Qur'an and their interrelationships. This atomistic method is considered to make the Qur'an's main mission of a certain theme blurred and unclear.

In addition, this tauhidi method also serves to know the dynamic movement of the Qur'an between the "universal" and "particular". Both of these terms are absolutely needed for clarity because with a clear distinction can be a foothold in applying the Qur'anic values at various spaces and time. Because primary mission of Qur'an is to build a universal base rather than a particular base.

The universal basis can always be accommodated in all dimensions of space and time, meanwhile the particular aspect is incapable of doing so. Particularity is always associated with historical and cultural context, as Syahrur's term local-temporal. Particular aspect is a verse related to a particular locality and is temporal, so it cannot be applied in different spaces and time. What is the basis of knowledge of the Qur'an is universal. To achieve universal idea requires a special carefulness to see the character of the universal, and according to Amina Wadud the universality of the Qur'an can be seen from the aspect of principle or morale idea. This principle is the point of emphasis in the hermeneutics of Amina Wadud in explaining the context and textual verse. The Qur'an revealed to Muhammad was not in the empty space. This view is the basis of the ontology of the Qur'an which constantly greets human. Indeed the Qur'an does not only belong to the Arabs alone, but the Arab became an early gate to further examine the values contained in the Qur'an, so it could be realized that the purpose of Qur'an is for the entire ages.

The understanding of the moral ideal emphasized by Amina Wadud is actually borrowed from Fazlur Rahman. ${ }^{7}$ Amina Wadud acknowledged that trough a concept of moral ideal introduced by Fazlur Rahman it can open the veil of spirit and mission that

\footnotetext{
${ }^{7}$ Amina Wadud, Inside the Gender Jihad Women's Reform in Islam (Oxford: One World Publication, 2006), 14.
} 
comes in every verse. But in the applicative meadow, we cannot say that she is exactly as similar as Fazlur Rahman's methodology which well known as double movement.

However, Amina Wadud also employed a methodological combinations by using structural analysis of language. In linguistic analysis, Amina Wadud used a paradigmatic method, which is an analysis of development of the meaning of language. Paradigmatic itself has three main focuses: speech language and its function (language act), the structure of sentence (syntactical structure), and the context of text when it is spoken (textual context). In this way, the paradigmatic step used by Amina Wadud is to answer some basic issues such as: what is mentioned by the Qur'an (syntactical structure), how it is said (language act), and what and who are around text when it is spoken (textual context).

Considering the theoretical framework model above, it can be underlined that the tauhidi hermeneutics of Amina Wadud requires some several phases as follows: 1) Historical context; 2) Context of discussion in the Qur'an; 3) The synonyms of language and syntax; 4) based on Qur'anic principle; 5) Weltanschauung or worldview of the Qur'an. All this interpretive movements have a plot of thought to find the spirit of the Qur'an in the form of principles and moral ideals. Therefore, this tauhidi model is also an extension of the Qur'anic interpretation with al-Qur'an, which is a method of interpretation that tries to link and seek explanation through other verses (inter-text of verses). ${ }^{8}$

The tauhidi hermeneutics as a paradigm can be understood in the application process to strengthen the equality of foundation between men and women. In this case the author gives an example of the role of men and women since the beginning of its creation. Here the writer will take a case of Adam and Eve creation which is in the knowledge of Islamic theology always call theological debate and often the story of creation is identified with Adam's error caused by Eve's temptations. This kind of belief led to a cynical view to male and female dialectics causing to label negative stereotypes against women who scapegoat for Adam's mistakes. In addition, from various interpretations of the early scholars also explained that Adam was the beginning of the creation of human beings as khalifah Allāh, while Eve was created from Adam's rib. This understanding emerged a unilateral view of the status of male domination over women.

Schematically, tauhịdi hermeneutics of Amina Wadud could be drawn as following picture:

\footnotetext{
${ }^{8}$ Ja'far Dikk al-Bab, "Metode Linguistik Buku Al-Kitab Wa Al-Qur'ān” in Muhammad Shahrur, Prinsip dan Dasar Hermeneutika Al-Quran Kontemporer, trans. Sahiron Syamsuddin and Burhanudin Dzikri (Yogyakarta: eLSAQ Press, 2008), 24-28.
} 


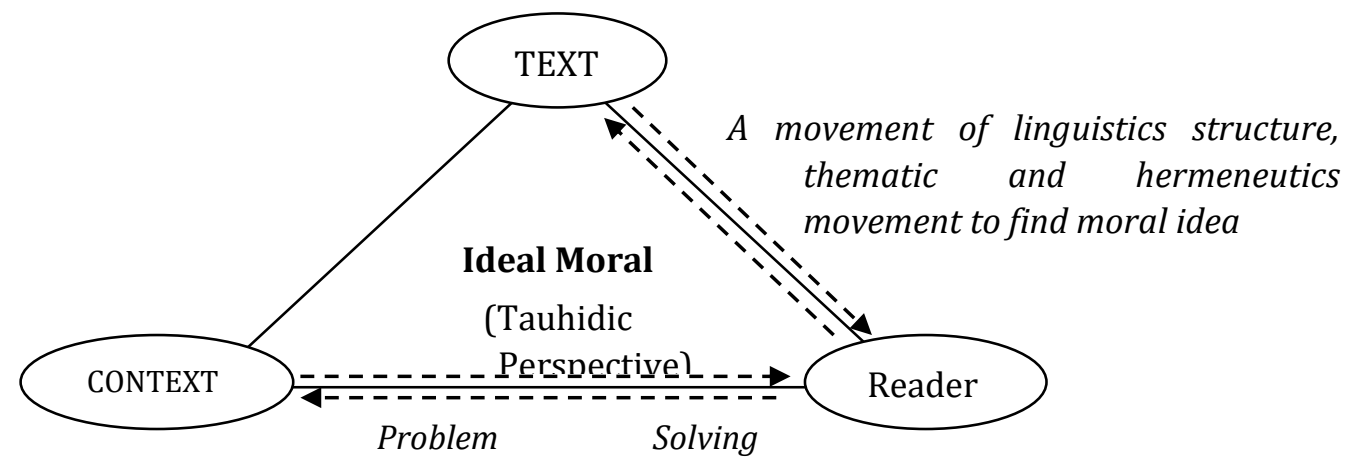

If it refers to the text of the Qur'an, all of the matters above are the opinions of the scholars in interpreting the QS. An-Nisa':1, "yā ayyuhā al-nās ittaqū rabbakum alladhī khalaqakum min nafsin wăhidah wa khalaqa minhā zaujahā wa baththa minhuma rijālān kathira wa nisa'an". The above verse is a fairly problematic verse in contemporary space and time, since it is often used as a theological foundation that legitimizes men above women. ${ }^{9}$

To explain and respond these controversial passages, Amina Wadud used an "allegorical" way (mutasyābihät). This approach looks that verses of the Qur'an cannot be understood in a simple way without imprinting the deep value. She quoted Kenneth Burke's opinion that "language is intrinsically incapable of comprehensively capturing the supernatural aspects of the outer text". Therefore the verses should be understood in many broad and deepest dimensions. By using this tauhidi paradigm Amina Wadud wants to restore all creation of creatures in equal position, there is no distinction between each other both men and women, because they compete to each other to achieve God's blessings. The most important aspect in the tauhidi paradigm used by Amina Wadud is to judge people not from the outward aspect or gender, but rather on the aspect of piety that can be achieved by anyone. ${ }^{10}$ Taqwa here does not only focus on the vertical aspect (individual-spiritual) but also linear with the horizontal (social) aspects, because taqwa is interpreted as an attitude and mental that can be an agent of social change. ${ }^{11}$

This tauhidi paradigm answers the problematic of the original human creation "monism", pivoted on Adam, into "dualism". This dualism view is inspired by lafadz "zauj" which means pairing. This couple became the creation keyword that this whole life is always created in pairs. So that Adam and Eve are a harmonious alloy created by God in an equal position, because they are equally instrumental in creating the next generation. ${ }^{12}$

\footnotetext{
${ }^{9}$ Amina Wadud, Quran and Women Rereading the Sacred Text from a Women's Perspective (New York: Oxford University Press, 1999), 1-3.

${ }^{10}$ Amina Wadud, Inside.., 14.

${ }^{11}$ AminaWadud, Inside.., 15.

${ }^{12}$ To strengthen this assumption, AminaWadudcorrelate this verse with others, such as, QS. 36: 36, 51:49, 43: 12, 35: 11, 53: 45, 3: 36, and so on.AminaWadud, Inside.., 21.
} 
Thus, the nafsun wăhidah contained in the verse is interpreted with a single soul in which his partner was created. And the couple does not mean must be submissive to nafs wăhidah, but more on the existence of a functional balance between the two in carrying the mandate to the caliph's. If there is no created partner for the nafs wăhidah, there will be no human development as it is today. So that the creation of both is a necessity of God's action in its mission to create "badal" in this earth.

\section{b. Dialogical Hermeneutics of Khaled Abou El-Fadl}

What became the stressing point of Khaled's discussion is to avoid the existence of authoritarianism in the determination of Islamic law. Authoritarianism, itself, begun when the process of determining and creating meaning happen. When the Mujtahids begin the process of surfing for meaning, they sometimes include subjectivity biases that often block the interaction between the elements in the text of the Islamic source itself. In fact, not infrequently when the mujtahid find the meaning that deems appropriate, they then claim that the meaning is the only thing God wants, and they also ignore other interpretations.

Therefore, in the study of sources for Islamic law, Khaled emphasizes on the process of negotiation (dialogue) between the three elements that surround the text; text, author and reader. ${ }^{13}$ All three must be proportionally dialogued in the process of meaning production. Tough the authority in reading a text is in the hands of the reader, but to what extent a reader respect the "integrity" of the author and the text itself, is a necessity to bear authoritative meaning.

Khaled classified the process of meaning determination into two model; authoritarian and authoritative. According to him, the authoritarian process of meaning occurs when a reader tries to "lock" the text in a certain meaning. ${ }^{14}$ Thus the reader seems to know what the author wants and also knows what the text wants. If so then, the reader has indirectly subordinated the role of the author and the text. Unlike authoritarianism, authoritative model is a thought that combines the three elements of the text (author, reader, and text) in a dialogical position to establish authoritative meaning.

Therefore, in the discourse of authority, to define an opinion whether it is authoritarian or authoritative; Khaled requires five principles that should be used as guidelines in the determination of meaning. The five principles are honesty, diligence, comprehensiveness, reasonableness, and self-restraint. ${ }^{15}$

\footnotetext{
${ }^{13}$ Khaled M. Abou El Fadl, Atas Nama Tuhan Dari Fikih Otoriter ke Fikih Otoritatif, trans. R. Cecep Lukman Yasin (Jakarta: PT Serambi Ilmu Semesta, 2004), 135.

${ }^{14}$ Khaled M. Abou El Fadl, Atas Nama Tuhan., 137.

${ }^{15}$ Khaled M. Abou El Fadl, Atas Nama Tuhan., 100-103.
} 
Schematically,dialogue hermeneutics of Khaled Abou El-Fadl could be drawn as following picture:

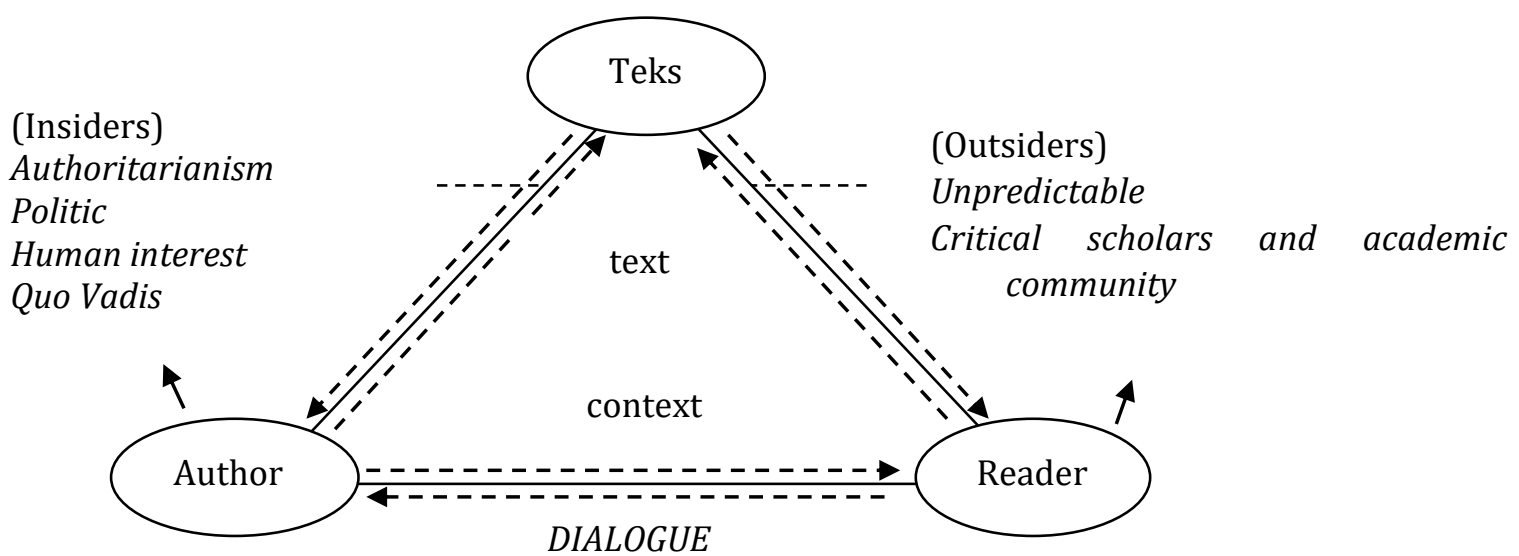

According to Khaled, the core problem of authoritarian law-enforcement is the process of research, understanding and hadiths reference as a non-comprehensive means of legitimacy. The understanding and the use of hadith has been done arbitrarily without further examining how the authenticity and historicity of the hadith both related to the whole involved in the process of transmission or content of information (matan).

In this case, the author proposes one example of misogynist hadith about the wives bowing (prostration) to their husbands. The Hadith is narrated in various versions and through various links of transmission by Abū Dawud, al-Tirmidhì, ibn Mājah, Aḥmad ibn Hanbal, Al-Nas̄a'i, and Ibn Hibbān. The hadith is as follow:

"Narrated from Azhar bin Marwān. He narrated that when Mu'adh returned from the Sham, he prostrated to the prophet. The prophet said; "what are you doing Mu'adh?" Mu'adh replied: "I just came from the sham and I saw the people there prostrate to the priest and the saints, and I also want to do the same to you". The Prophet said: "If I had to send someone to prostrate to other than Allah, I would have a wife prostrate to her husband. For God's sake, a wife has not been deemed to have fulfilled her obligation to God until she fulfills her obligation to her husband, and if she is asked to serve her husband (having sex) while she is on camel, then she should not refuse her husband's request. "

According to Khaled, that hadith and similar one have many peculiarities. He termed it wakhdz al-damir (something that disturbs consciousness). This means that the hadith if viewed from a humanistic perspective will disturb the human nature that he is not in line with the teachings of Islam which basically wants to raise the dignity of women. 
According to the hadith scholars, the authenticity degree of these traditions is varied, ranging from the da'if (weak) to the hasan gharib (good). All of these hadiths cannot reach to mutawatir degree. However, the implications of that hadith are very great, whether at juridical, social, or theological realm. Women are God's creature entities as well as spouses for husbands placed their position only as complement, not as partner to run the household's affairs.

Therefore, a woman must obey the husband in all sides of her life. For example a wife is not allowed to leave the house without her husband's permission. The wife is not allowed to do optional fasting without her husband's permission, and when the husband is passionate then the wife should immediately serve him, and so forth. The concept of obedience of wives to husbands, besides the hadith above, usually refers to the Qur'an surah an-Nisa': 34, where the word qawwämün is often used as the theological basis for the husband superiority. In fact, according to Khaled, the paradigm that carried by the Qur'an about the household never used word ta'ah but it more emphasized on the concept of mawaddah wa rahmah. ${ }^{16}$

In addition, the hadith also contains some gaffes and tends to contradict with Prophet's behavior. A hadith narrated by al-Bukhāri, for example, told us that Umar's wife when she was arguing with Umar said: "you are angry to me because I argue yourself. In the name of Allah, Prophet's wives argue to prophet also. Even one of them leave him at morning to night." It is affirmed by another hadith narrated by Nasa'i explaining that Prophet never slapped, mocked one of his wives. His treatments to his wives were very gentle, and he always asked his wives for some suggestions. ${ }^{17}$ Based on this hadith, it is quite clear that the Prophet placed his wives as partner to build a harmonious family. And he was not an authoritarian.

According to the hadith scholars, the degree of authenticity of these traditions is varied, ranging from the dha'if (weak) to the hasan gharib (good), all of which are not up to the degree of mutawatir. However, the implications of the above hadith are great, whether juridical, social, or theological. Women as God's creature entities as well as spouses for a husband placed his position only as a complement, not as a partner in running the household. Therefore, women must fully obey the husband, including in all sides of his life. For example a wife is not allowed to leave the house without her husband's permission, the wife is not allowed to fast the sunna without the permission of the husband, and when the husband is passionate then the wife should immediately serve him, and so forth. The concept of obedience of wives to husbands other than the above hadith, usually refers to the Qur'an surah an-nisa ': 34, where lafadzqawwamun is often used as the theological basis for

\footnotetext{
${ }^{16}$ El Fadl, Atas Nama Tuhan, hal304.

${ }^{17}$ Ibid., hal 311.
} 
the power of the husband. In fact, according to Khaled, the paradigm that carried by the Qur'an about the household never use lafadzta'ah but more emphasis on the concept of mawaddahwa rahmah.

Examining the language context and structure, the above hadith also contains an element of ineptness. Is it possible that the Prophet said that a wife should fulfill the husband's desire despite of being on the camel's back? The Hadith precisely describes how the behavior of a man who cannot hold his lust and the prophet seemed to legalize the behavior of lust of lust. Therefore, this tradition does not describe the wisdom of a Prophet, but rather implies the legitimacy of the prophet against the lust of a man who is quite savage. In other narrations there are also additions that seem unfit if it is uttered by the Prophet. Therefore, according to some Hadith commentators, the hadith has undergone an extraordinary addition (fí ghāyah al-mubālaghah). ${ }^{18}$

When it looked from the narration aspect, Khaled also observes that in some narrations there is Abu Hurairah who is considered as a quite controversial narrator regarding misogynist traditions. In addition, he was criticized by some companion such as' Aisyah and Umar. Abu Hurairah is also known as a companion who mixes a lot of mixture of teachings between Islam and Jews in the Talmud. His togetherness with the Prophet just in three years also gives prejudice toward the traditions narrated by him. ${ }^{19}$

Therefore, in order to find the authenticity of the hadith above, Khaled applied the principle of "pause of thoroughness", which is to ponder for a moment to establish the position and impact of those traditions. ${ }^{20}$ In other words, he delays meaning determination before reaching a strong conviction. Based on some of the facts described above, Khaled concludes that the hadith narrated about the prostration of a wife to a husband is deemed flawed and can not be made a foundation in the law.

In this case, it appears that Khaled has done some steps he has formulated to examine the hadith. It started from matan aspect by investigating of the structure of language, confirming with Qur'anic verse, moral values, intellect, and also conducting an investigation of the chain of transmission, and considering the condition of the historical context and the moral and social consequences of the hadith.

\section{Integration of the Tauhidi-Dialogical Paradigm}

Stand on the two thinkers above, it can be underlined that the two thinkers have different formal and material objects, although they have similarities in discussing the major themes of gender. Both paradigms and methodologies that have been initiated by the

\footnotetext{
${ }^{18}$ Ibid., hal 312 .

${ }^{19}$ Ibid., hal 312-313.

${ }^{20}$ Ibid., hal 308 .
} 
two thinkers above do not close the possibility of synthesis process that can be applied in any reading on religious texts. The tauhidi paradigm as described above is based on two strategic steps, namely as a paradigm as well as methodology. Such is the case, the dialogical paradigm of Khaled Abu El-Fadl requires a consideration of elements surrounding the text certainly cannot be thrown away by accentuating the reader aspect. If so then what happens is arbitrary arbitrary authority in determining Islamic pragmatic values. These two points of view are actually very likely to be integrated in the area of methodology and approach.

The concept of tauhidi which refers to the thematic commentary method, ayat bi al$\bar{a} y a t$, is an attempt to dialogue between verses to find the meaning contained in it. The effort to establish the meaning is also supported by the historical testimony and social dynamics of the society that surrounded it at the time. So the role of context in determining the meaning of the text of the Qur'an is very important in order to bridge the gap maknawi between contemporary times and classical times. Thus, the more text-oriented (thematic) thematic method requires applying to other hermeneutic elements in the context and reader. This is possible for a comprehensive meaning based on the logic of the historicity of the text. Similarly, the triadic concept of hermeneutics must also be paradigmatic, in the sense that the three elements must unite negotiate and dialogue to establish a flexible, credible, accountable and able to answer the challenges of the times.

This tauhidididialogical model allows for a comprehensive reading, in which hermeneutical aspects will be answered and the text in the Qur'an will be interpreted holistically, since it covers the entire dialogue of text related to the studied texts.

\section{E. Conclusion}

Two modern Islamic thinkers above representing contemporary thoughts have the same anxiety in responding to gender issues and positions of women's identity. Both have different approaches and methods approaching the sacred text. Amina Wadud who has a higher orientation toward Qur'an exegeses has her own method to study religion text, namely tauhijdi hermeneutics. Her hermeneutics was able to answer some ideological background of interpretation that tends to discredit women by strengthening the spirit of human creation which is naturally equal. Meanwhile Khaled Abou El-Fadl whose focuses is on more hadith, shows that misogynist traditions do not meet a demand of acceptance qualifications for ideal text ( hadith sahịh). Khaled uses dialogical hermeneutic to suppress the concept of authoritarianism in a construction of religious texts meaning. He concluded that a misoginis interpretation derived from texts of hadith did not have a strong foundation and it shows an epistemological fragility for those giving fatwa. 


\section{Bibliography}

Abdullah, Amin, "Pengantar Rektor UIN Sunan Kalijaga" dalam Susilaningsih dan Agus M. Najib, Kesetaraan Gender di Perguruan Islam; Baseline and Institutional Analysis for Gender Mainstreaming in IAIN Sunan Kalijaga, Yogyakarta: UIN Sunan Kalijaga dan McGill, 2004.

El Fadl, Khaled M. Abou, Atas Nama Tuhan Dari Fikih Otoriter ke Fikih Otoritatif, terj. R. Cecep Lukman Yasin, Jakarta: PT Serambi Ilmu Semesta, 2004.

Arfan, Mu'ammar M. dkk., Studi Islam Perspektif Insider/Outsider, Yogyakarta: IRCiSoD, 2012.

Murata, Sachiko, The Tao of Islam; Kitab Rujukan Tentang Relasi Gender Dalam Kosmologi dan Teologi Islam, terj. Rahmani Astuti and M.S. Nasrullah, Bandung: Mizan, 1998.

Shahrur, Muhammad, Prinsip dan Dasar Hermeneutika Al-Quran Kontemporer, terj. Sahiron Syamsuddin and Burhanudin Dzikri, Yogyakarta: eLSAQ Press, 2008.

Umar, Nasaruddin, Argumen Kesetaraan Jender Perspektif Al-Qur'an, Jakarta: Paramadina, 2001.

Wadud, Amina, Inside the Gender Jihad Women's Reform in Islam, Oxford: One World Publication, 2006.

-----------------, Quran and Women Rereading the Sacred Text from a Women's Perspective, New York: Oxford University Press, 1999.

Wijaya, Aksin, Menggugat Otentisitas Wahyu Tuhan: Kritik Atas Nalar Tafsir Gender, Yogyakarta: Safiria Insania Press, 2004. 